\title{
A Historical Study of Ekbatana Hill and a Glance at its Rehabilitation
}

\author{
Asghar Mohammad Moradi*1 ${ }^{1}$, Alireza Saboori Fard ${ }^{2}$ and Fatemeh Nassabi ${ }^{3}$ \\ ${ }^{1}$ Associate Professor, Department of Restoration, Iran University of Science \& Technology, Iran \\ ${ }^{2}$ Architect, Department of Restoration, Iran University of Science \& Technology, Iran \\ ${ }^{3} \mathrm{Ph}$.D. Candidate, Department of Architecture, Iran University of Science \& Technology, Iran
}

\begin{abstract}
Ekbatana Hill, with a length of 1,000 meters and width of 500 meters is located in the north east of Hamedan city. According to both Iranian and foreign archeologists and historians, Ekbatana Hill is the remains of ruined imperial palaces of ancient Hamadan belonging to the Median, Achaemenid and Parthian eras. The remains found on the hill and some gold and silver tablets indicate that it flourished during the Achaemenid era. Hamadan was to all appearances, the summer capital of pre-Islamic government; therefore the palaces built on the hill were decorated with precious things of the time, which have been plundered during wars.

This research is an approach to the study of the historical hill, which is now located in the center of Hamedan city. It is certainly not expected that the hill has any position in the new current civil functions, but its occupation during recent decades needs a substantial review. On the other hand, the hidden layers might sometimes endanger the hill, due to lack of facilities. It is in need of a new observation, in order to properly share parts of the existing remains of the hill, especially the fortification wall, in the current civic life and assign it as a part of the city edge. So, the study of historical traces on one hand and urban renovation theories on the other can be an effective approach.
\end{abstract}

Keywords: Ekbatana; historical hill; restoration; renovation; historical wall

\section{Introduction}

Since human beings started to live in small and large civilized urban and rural communities, urban records and the appearance of communities can be seen in Hamadan. According to this, Hamadan is considered as one of the oldest cities in Iran as well as in the world. Using prehistoric remains, including earthenware, gold and stone tablets, archeologists have identified some shepherd communities on the hillside of Alvand Mountain - situated in the western part of Hamedan city — dating back 5000 years.

In the 2 nd millennium B.C. Kasians, who were shepherds, lived in separate groups in the western regions of Iran and in organized communities in the Zagros Mountains. Because they had the greatest influence on the central parts of the Iranian plateau, historians believe that words like Ghazvin, Kashan and Khazar may have derived from the word Kasi. As stated in the Torah, Ahmata is the Hebraic name of

*Contact Author: Asghar Mohammad Moradi,

Associate Professor, Architect, Unit 4, No. 4, 10 meter street, Ne'mati Avenue, Hekmat, Gheytariye, Tehran, Iran

Tel: +98-912-179-2655 Fax: +98-212-220-6212

E-mail: m moradi@iust.ac.ir

(Received October 8, 2007 ; accepted June 5, 2008)

\section{Hamedan.}

The earliest appraisal of Ekbatana refers to the Assyrian tablet (1100 B.C.) which named the city, Amadana. After the immigration of Indo-European families to the Iranian plateau, this city was erected as the first capital of the Iranian Empire (a branch of Iran, called Median).

It seems that the city was built on a great hill with soft soil. Also, the imperial palaces and treasury were located on the high hills of Alvand Mountain. The other walls accommodated administrative, martial, military, civil, and religious sections. The common people lived in the last enclosure or outside of the fortresses in their sun-dried mud brick houses as usual, while expensive cypress wood and pine - evenly coated with silver and gold — were used in the palace buildings.

\section{Origin of Ekbatana}

The territory of Mad was named Mada in Achaemenid tablets, Mazya in the works of Greek historians, Amaday in Salmansar the Third's tablet dated 835 B.C. and then Matay and Maday in Assyrion works and in Mesopotamian inscriptions. It was called Maday because it probably refered to the north western region of Iran, Oman Maday, where Diyox unified the Iranian nations and installed a government in the 8th 
century B.C. Historians differ on how the city was developed and by who.

Ketsias, the Greek historian and personal physician of the Achaemenid emperor, Ardshir the Second, attributed the establishment of the city to the Assyrian queen, Samiramis:

"Having seen the site, Samiramis, built a palace on it, but as the site dried, she ordered the building of a costly canal in order to convey the water of the lake beyond the Alvand Mountain to the site" (Jacksen, 1978).

In the "Torah" the founding of the city has been attributed to Arfkshad. Some architectural properties of the city have been described in this book, which also mentions that Nabkodnasr, the Babylonian king, destroyed the city between 562 and 604 B.C. (Jacksen, 1978).

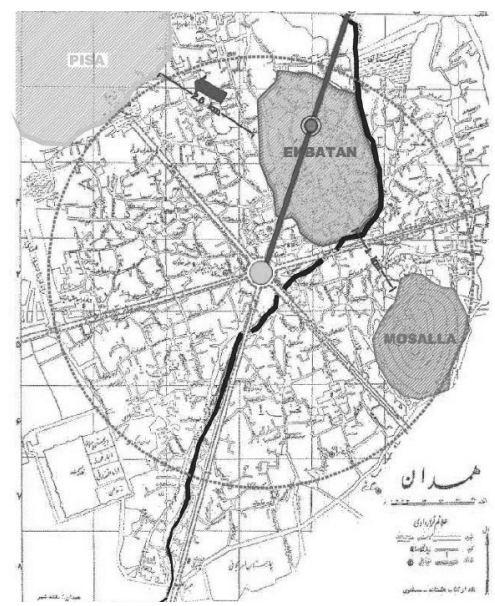

Fig.1. Site Plan of the Present-day City of Ekbatana, Scale: 1/20000 (Survey Organization, 1996)

Herodotus, the famous Greek historian, named Diox as the founder of Ekbatana. Diox the first emperor of Median ordered the building of Ekbatana Palace following alliance of the Median tribes. This palace was described by Herodotus as follows:

"...so Diox developed the Ekbatana, with huge and strong fortification walls around one another. The palace design is such that each wall is taller than the next one by the amount of its indention only. Although this topographically suitable hill is somewhat appropriate to the aforesaid arrangement, in general the work of art itself has made it effective. The number of walls is seven. ..." [1] Thus he introduces these walls: white, black, red, blue, orange, gray and yellow, respectively.

Fisagures (6th century B.C.) is another Greek historian who gives a glorious description of the city.

"The Moghan Ekbatana" is a village on the peak of a high mountain which is visible from a far distance, like luminosity and is distinguishable from other places. When the sun rises to meridian it glitters as a glowing point in the sky. The closer you get the stronger illusion you will have. To reach there you must pass through seven enclosures, each overlooking the other. The walls are distinctly colored in white, black, blue, sapphire, red and orange and there are gold and silver walls as well..." (Jacksen, 1978).

One can imagine the hierarchy and the style of color in the hill.

Polybius, the roman historian, (204-222 B.C.) thought that Ekbatana was the Median capital, and described it as an excellent city. He says the city did not have any fortification walls, but it was located on a huge platform. He also steers readers away from exaggerated descriptions of the city by historians. Western historians attributed the foundation of the city to Samiramis, Arfkshad and Diox, but eastern historians named others as the founders of ancient Ekbatana. For example Toos Salmani, Ebne Faghih and Khazraji cite Dara as the city founder, for Hamedan Shahrdara was the son of Dara (Hamedani, 1970). Yaghoot Homavi [2] believed that Hamedan was named for Hamedan Ebn Flooh Ebn Sam ebn Nooh and the founder of the city was Kermis ebn Halimoon. Regarding the situation of the city, several Islamic scientists have noted some of its characteristics in their books.

By studying historical documents, archeologists' comments and discovered relics of Ekbatana (Hegmateine) one can acquire an unclear image of the ancient city, the earliest capital of Iran, as follows:

Although according to Assyrian tablets, Ekbatana was founded in the late second millennium B.C. there is no clear evidence of this era. Based on descriptive reports, Ekbatana was erected on the hillside of Alvand Mountain and had seven huge fortification walls as high as those of Athena, while the interior walls were higher than those in Athena, so that the significance and firmness of seven encircling fortresses could be clearly seen from a distance. As seen in engravings on Assyrian tablets, Eilam's enemies were constantly plundering Made (a neighboring country of Eilam) forcing the Medians to make fortresses as firm as possible in their capital. These citadels were even more reinforced than their other cities, like Khar-khar (with one fortification wall) and Kishsum (with several fortification walls).

\section{Architectural Characteristics}

In the existing boundary of Ekbatana Hill, which has been excavated and studied by archeologists, the remains of an ancient city have been discovered

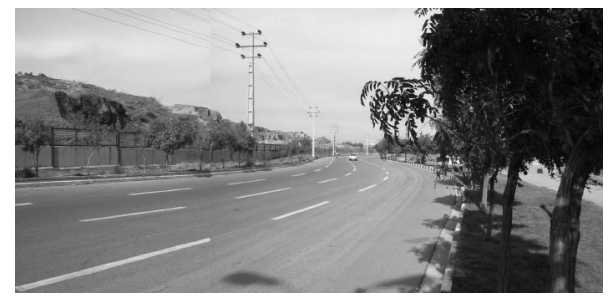

Fig.2. A View of the Existing Boundary of Ekbatana Hill 
located alongside a fortification wall. The natural and geographical factors are the most substantial characteristics of this site. Historical studies beside geographical conditions imply two considerable environmental factors which have definitely been taken into consideration by its constructors: Alvand Mountain and Nazarbeik River.

The first had a pivotal role in fortress resistance both physically and metaphysically. The second, Nazarbeik River, played the role of a natural moat in the fortress so as to make it impossible to penetrate the castle.

The city is formed by an orderly pre-designed plan which has no similarity to any other ancient type in Iran. In studying the other types in the world we could hardly compare it with Tel-Al Emarne (Mouris, 1989) [3].

The city has parallel neighborhoods and equal pathways, which are located at a distance of 35 meters from each other. The pathways are 3.5 meters wide and two attached houses with dimensions of $17.5 \times 17.5$ meters are flanked by them. The pathways are oriented in a northwestern-southeastern direction (Fig.3.). Only seven paths have been discovered so far, one of which is 17.5 meters to the adjacent one. Therefore the city has two architectural areas (Sarraf, 2001).

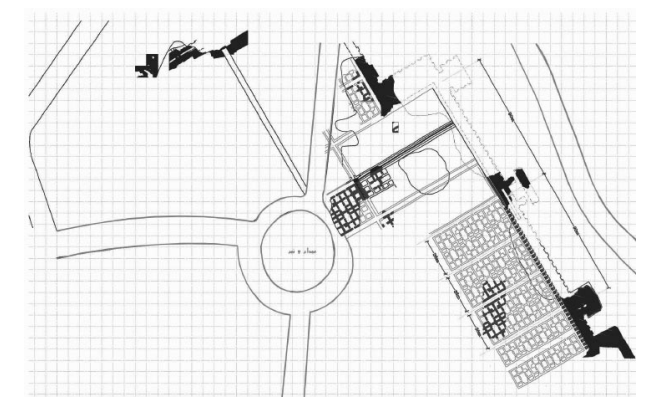

Fig.3. General Plan of the Historical City and its Fortification Wall, Scale: 1/600 (Cultural and Heritage Organization, 2001)

The first includes two rows of adjacent buildings and the second one row of buildings.

In architectural style, even the dimensions of the houses in the two regions are the same. One of the developed urban facilities is its water supply system discovered in water supply canals in the form of a water ditch constructed of brick and gypsum, with lime mortar behind the wall and also in one of the pathways. It seems that the city's architects accomplished the distribution of water in the city precincts in a planned network. A small pond with dimensions of $1.5 \times 1.5$ meters and one huge well at a distance of 2 meters were discovered in part of the ditch, but the well does not seem to be an old one. (Zarehyee, 2000).

Regarding the water supply canals, it seems as though this stream drained out of the lake on the other side of Alvand Mountain, or it is likely that this canal was built for disposing of the city's drainage water and sewage.
A survey of the architectural system of the ancient city regarding the establishment of pathways indicates that the discovered pathways established communication between people in a northeast to southwest direction. Also, there is no evidence regarding how the inhabitants of ancient cities communicated with each other.

There are two viewpoints concerning such communication:

A hierarchical system of pathways was accomplished in the form of one-way distribution from the main pathway (adjacent to the wall) to secondary pathways.

There were other arterial pathways parallel to the pathway adjacent to the wall, which has not been discovered as yet and the secondary pathways (the pathways between houses) linked these two main pathways to each other.

Although this system of mesh distribution and availability of pathways along with increasing the length of subsidiary pathways does not seem to function properly, it is justified by the discovery of the aforesaid pathway, and by taking account of the fact that this fortress was a military defensive stronghold.

However, accepting the Herodot theory of seven fortresses around Ekbatana and assuming that the location of the Median fortress is the Sar-ghal-eh Hill of Ekbatana, the perimeter of the city's biggest fortress was about 4,000 meters which was, according to Herodot, the same size as the Athena wall. The radius of the external wall at the most reaches to 600 meters and other walls were set at regular intervals in the form of concentric circles. On the basis of the above accounts, the distance between each wall was 65 meters, so that with regard to the relative thickness of the walls, the distance between them would be different by from 40 to 50 meters (Saeednia, 2001).

In this case, the probability of the existence of another pathway is eliminated, so the next fortress is substituted for it.With regard to the floor brick, which is found only in pathways with a water ditch, what we can say about the quality of the pathways is that they had probably been covered by some materials ruined as time passed.

Considering the architecture and style of the houses between these pathways we can say that they are all

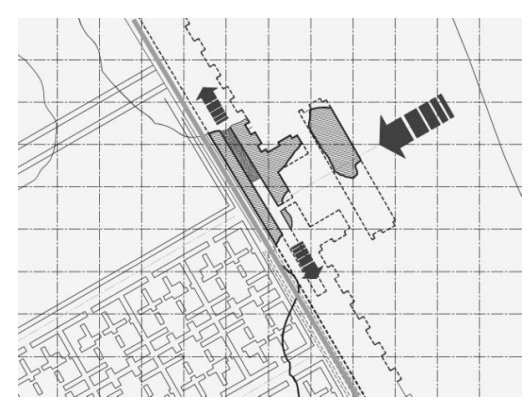

Fig.4. The Probable Entrance to the Wall of one of the Towers. The watercourse in depth of the wall which was probably used for water distribution to the city, Scale: 1/500 (Saeednia, 2001) 
the same and that the architects did not make an effort to build houses with different plans in any of the eastern areas. Although, some changes are observed in a pathway with brick floor discovered in the north part of hill, according to the evidence these changes around the aforesaid pathway are in order to alter direction and this could be the reason for the existence of pathways with an opposite direction to previous pathways. This strengthens the theory of the existence of an arterial pathway adjacent to the wall. Houses have one entrance room and a rectangular yard in the back and there are 3 rooms around them, totaling 6 rooms; (Sarraf, 2001).

The typical characteristics of house architecture in Ekbatana are as follows:

- Concise plans appropriate for the cold climate of the Ekbatana area and linked to each other from 3 sides

- The separation of general and private spaces by designing two general and private division spaces

- The central yard with a veranda pattern

- Especial architecture with minimum number of windows looking outside and capturing light from the central yard.

All of these characteristics qualify the plans to be compared with the advanced typologies of Persian architecture in the golden eras.

One of the most important installations of Ekbatana was the tower and fortification around it. The thickness of the city wall was 9 meters and it was built with sundried mud bricks. About 600 meters of this wall has been discovered up to now and some parts of it have been excavated. About 50 centimeters away from the city wall, the watercourse was built from the southeast to northwest in definite distances from it. There are towers along the wall at a distance of 90 meters from each other and it seems that some of them are hollow and some solid. As Achaemenid architecture some of these towers are ceremonial. What can be understood from the plan of the wall is that it is not circular or rectangular. It is a polygon and in some parts of the wall a corridor about two meters wide has been discovered, which was probably designed for moving inside the walls and entering the city. This may be because of the economic feasibility of materials. The wall has been designed in consecutive pillars and elevations, and in some parts white plaster is visible on the facade [4].

The dimensions of the discovered pillars are about 2.1 and 2.7 meters and the only remaining profile is about 4 meters long and 1.1 meters wide (Sarraf, 2001). The materials used in Ekbatana are mainly sun-dried brick. In some parts a brick foundation is used for the sundried brick walls and the ceiling was made of wooden beams and columns. Various sizes of sun-dried brick were used in the fortification wall. The existence of smaller sun-dried bricks at the bottom of the wall and bigger bricks with irregular arrangement at the top show two different periods of architecture, which may have resulted from the destruction of the upper parts due to invasions and quick renovation. Small and big niches as well as thick layers of plaster and lime on the earthen walls, which confirm three different periods of living in the city indicate other characteristics of this era (Saghafi, 2000).

The similarity between adobe bricks in Perspolis and those of Ekbatana and dissimilarity to the bricks of other Median sites like Godin Tepe [5] and Tepe Hamekasi reveal the fact that the Median Settlement in Ekbatana is not clear. However it may be a sign of Achaemenid presence in Ekbatana in the following period or even a kind of imitation from Median architecture in building Perspolis by the Achaemenid emperor whose summer capital was Ekbatana. Although proving the case is not an easy task we can see other examples of the Achaemenid's imitation of Median architecture in their platforms, typology of amphitheaters with Apadana columns, Rock Tombs, and wooden ceilings and columns, using aboriginal materials and false windows (Mehryar, 1982).

During architectural studies the archaeologists have found a mass of adobe bricks with 25 meters thickness (Sarraf, 2001). The existence of this thickness in the wall could be a sign of the earthen platform, which was a part of this fortification wall. This pattern was chiefly used in Median architecture in order to change the natural slope of the land into a vertical slope and building hybrid walls, which were overlooked by each other (Sarraf, 2001).

Finding additional remains with different dimensions of adobe brick shows a reinforcing pattern for walls following its destabilization resulting from damage (Diacnof, 2000). Also, the finding of different things during excavation of the city outskirts such as flat seals, coins, plinths, small pottery sculptures and glass etc, shows how the city functioned in different periods (Saghafi, 2000).

There are some vague points regarding the reconstruction plans of the fortification wall on the basis of excavated trenches, which require extended study of Median architecture and effective civilization in order to complete the main lines of the wall (Fig.5.).

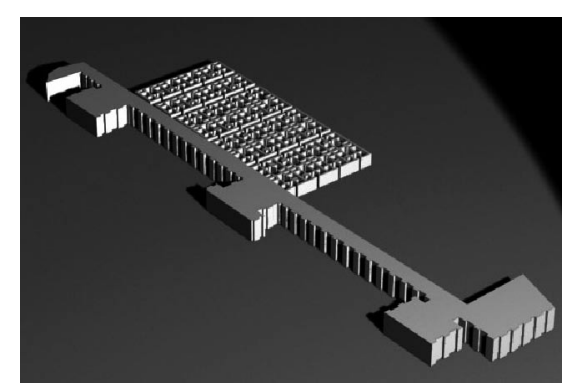

Fig.5. Archeologist's Suggested Design of the Reconstruction Plan of the Ekbatana Wall, that seems to have some Ambiguous Points in the Wall Corners 


\section{Wall Abstraction}

According to studies concerning Median architecture, in the first period before formation of the united Median, in archaeological sites and Assyrian tablets discovered in the Third Thiglatpelser Palace in Khorsabad and also the Second Saregon in Nimrood, the main characteristics of Median architecture (fortress) can be summarized as follows:

1. Most of the Median cities were built on either natural or artificial platforms.

2. Some of the cities were built by a river and in such cases the river acts a natural moat for the city.

3. Most of the Median cities have a defensive fortress in which people could take refuge in time of danger.

4. The location of these fortresses was usually by a river or natural lake.

The Common parts of this fortress consisted of a fortification wall with a number of towers.

5. There were usually 7,8 or 9 , or there may have been more towers, which were regularly positioned on the walls.

6. In some of these fortresses a second row of walls was seen on the top of the first wall.

7. In the usual form of these fortresses, there were vertical rows of rectangular hatches at the junction of the wall and tower.

8 . The upper part of the wall and tower was adorned with battlements for shooting at the enemy and sometimes in terms of traditional belief; a deer's antler was set on these battlements.

9. Use of vernacular materials.

10. Certain parts of the tower, which were made on top of the wall were wider and had two rectangular hatches.

11. There was at least one arched entrance in the lowermost part of the defensive wall and sometimes also in the lower part of the second row of the wall.

12. Using sun-dried brick, brick and engraved overlays in interior decoration.

13. Using decorative windows on some parts of the building facade.

14. Using wooden beams and a flat cover for the ceiling.

15. Appearance of ceremonial architectural patterns and columned auditorium with regular wooden pillars.

As mentioned before, some parts of the Ekbatana wall with a length of 260 meters have been discovered. It is not known whether this wall is the innermost or outermost wall of the city. All we know is that the wall has a polygon geometry and the two clear towers on it are 90 meters apart from each other. On the other hand, within the 260 meters there are some lines which are invisible and we can complete them by extending the lines and existing rhythm. By studying the remaining parts of the wall, it seems that the most important ambiguity is in the breakage of the wall's path (on the northwest corner). Since the direction of the wall has changed at this point, the resulting joint needs more study. The archeologists proposed plan of this area requires substantial review, from the military, defensive and even architectural typological point of view.

In a comparative studying one might consider the plan of the Rahmat Mountain Wall of Perspolis as a more advanced type of this fortification wall in Ekbatana, as there are similarities in the projecting towers, the middle passageway of the wall and the rhythm and elevation of the pillars. Godin Tepe, among other Median architecture also has patterns in common with Ekbatan. Especially in the towers, some of which are solid and some hollow. From the typological and chronological point of view the architecture of the Ekbatana wall can be evaluated somewhere between Godin Tepe and Perspolis.

An important issue in comparing the plans of Godin and Nooshinjan with the Perspolis wall is the similarity of patterns in the design of warehouses, which assists the Achaemenid imitation of Median architecture.

In analyzing and abstracting the unknown corner of the wall we should consider that the wall typology of Median, Manay, Urarturien, and other related civilizations shows that although the towers have been positioned at equal distances on the wall this placement is approximate and may alter when there are more important problems like designing the joints and corners.

In these cases symmetry would be replaced by proportion and equilibrium. Since Urarturian fortresses have undeniable similarity to Iranian ones, the existence of towers at the corners is definite and this fact can be investigated in polygon fortresses. Studying these walls and other Median examples, we can eventually present alternatives concerning the unknown corner (see Figs.6.-9.). To achieve an imaginary plan of the Ekbatana wall elevation, there is a need to compare other similar walls. Historical studies show that the influence of Urarturien civilization on the formation of Median fortress architecture is greater than that of others (Sarfaraz, 2001).

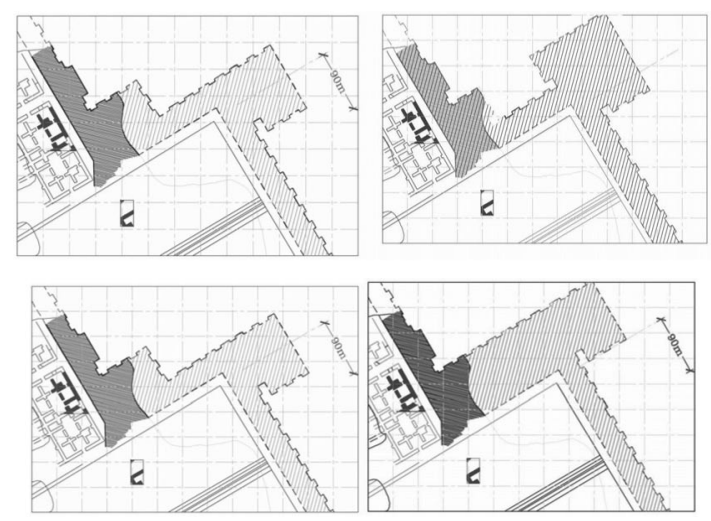

Figs.6-9. Different Alternatives for Unknown Corner of Wall, According to Comparative Studies with Median, Urarturian and other Related Examples 
Meanwhile, neighboring civilizations, such as Manian and others like Assyria, Babel and even Ilam who were enemies of the Median emperor affected this formation. To this end, after providing some architectural characteristics of Median fortresses, a revision will be carried out concerning the architectural characteristic of walls belonging to various civilizations in which they have imitated each other.

\subsection{Manian fortification walls}

According to field observation in Hasanloo Tepe and also to Manian engraved tablets, the main characteristics of Manian walls will be summarized as follows:

- Equal distribution of towers on walls.

- Arched entrances.

- Using rectangular windows in towers and not in walls.

- Covering platforms and floors with brick or sundried bricks.

\subsection{Babylonian and Assyrian Walls}

The most important characteristic of these walls was that they were thick enough for the armies and horses to move on top of. They were usually built with two separate internal and external walls which were filled with small stones, while the external one was mostly built to be more resistant (King, 1987).

Their proportions were usually higher and wider in comparison with Median ones. One of the characteristics of Babylonian walls is the vertical furrows and height difference in the entrance using steps. They also had circular windows instead of rectangular hatches. In these walls, battlements and projected buildings are found on the towers and sometimes two different materials were used in the base and upper parts of the wall - adobe and brick respectively.

\subsection{Urarturian walls}

Perhaps the most important picture that shows the characteristics of Urarturian wall elevations is the bronze plaque in the picture (Van Loan, 1960). The most important finding of this picture is the form of the battlements, the rectangular windows, the arched entrance and upper projection of the tower, which casts a shadow on the building (Fig.10.).

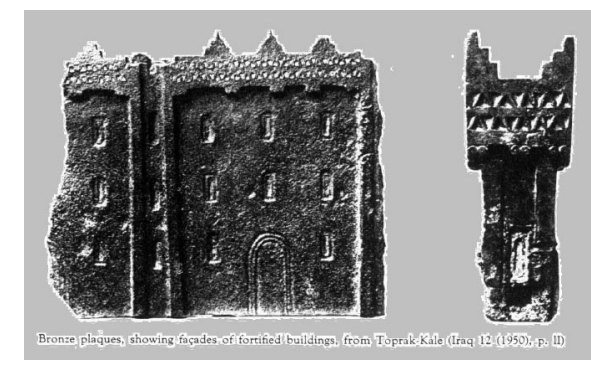

Fig.10. An Engraving of the Profile of Urarturian Walls shows the Details of Battlements, Decorations and Hatches (Van loan, 1960)
In perusing other tablets remaining from Urarturian architecture, more characteristics will be added to these findings which include:

- The wall geometry as a polygon.

- Using rectangular entrances instead of arched ones in some of the walls

- Reducing the wall thickness while increasing its height.

- Using rectangular battlements in some of the walls.

- Height equality in towers and walls.

\subsection{Ilamian walls}

In spite of some differences, the elevation of battlements in Ilamian walls, have common characteristics with Median fortresses. Rectangular hatches cannot be found in Ilamian towers, as there is usually an arched entrance in the center of the first tower (Sarfaraz, 2001). In some Ilamian walls, the lower part of the towers is wider than the upper part.

Feasibility of the abstract form of the wall and possibility of a resemblance between these walls and the Hegmatane wall is necessary before any plan can be proposed. Some quantitative information such as dimensions, color, number and size of the gates, windows and other parts of the elevation is needed. All the authors have as documents are some historical reports, which should be adapted to the existing trenches in the site and eventually three alternatives for the fortification will be drawn.

Jacksen, quoting from the Torah gives some of the historical reports as follows:

"He built walls with the stone which measures 3 cubits wide and 6 cubits long and also a wall with a height of 70 cubits and width of 50 cubits all around Ekbatana. And on its gates he made towers with a height of 100 cubits [6] and width of 60 cubits. And he built gates for them with a height reaching even 70 cubits and a width of 40 cubits, so that his strong army could pass through it and his infantries could march on it in a line." (Jacksen, 1978).

As noted in Albaladan:

"Bokhtonnasr, the head of the army who had surrounded Hamedan, wrote to him: 'I got to a crowded and wide city where its walls are high and strong and its entrances are very wide. The city extended from the mountain domain to the village named Zinooaban.' And he built a great palace in that city and named it Saroogh. The workers hurried to build the city and made three hundred special places to hide all the money and treasures in the palace."

They built seven iron gates for the city, each with two door leaves. Each leaf was 12 meters high, and then he built another palace for relatives and family and for keeping the money. He hired 12 watchmen to protect the city (Hamedani, 1970).

According to Herodot:

"So Diox built Ekbatana city with 7 solid and huge towers side by side all around it. Each of the towers 
was designed to be taller than the other by as much as the height of a battlement. There are 7 walls with white, black, red, blue, orange, silver and golden colors respectively" (Evans, 1964).

Regarding the authors' findings and knowledge regarding the history and architectural patterns of Ekbatana Hill, it is possible to abstract the following designs for it.

Finally, according to the fact that the authors have the history and architectural patterns of Ekbatana Hill, we may imagine its design as shown in (Figs.11.-13).

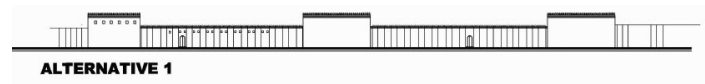

Fig.11. A View of the Imaginary Restoration; the First Alternative

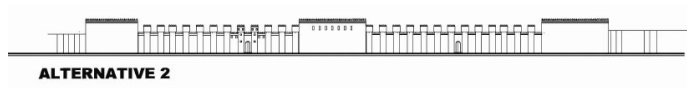

Fig.12. A View of the Imaginary Restoration; the Second Alternative

$\frac{1 \mathrm{~min}}{\text { aLternative } 3}$

Fig.13. A View of the Imaginary Restoration; the Third Alternative

\section{Conclusion}

Reviewing the historical information and architectural characteristics of Ekbatana, especially the fortification wall, as well as observation of the destroyed ground level remains has led the authors to form a mental image of this wall. In respect to restoration principals, it is prohibited to reconstruct the wall as it was before. In addition, the existence of the hill in the central area of the city and its situation in the current urban development of Hamedan, create two positive and negative potentials regarding the rehabilitation process as follows:

A- Positive potentials of the hill in the city:

1- Settlement of the original site of the city in the mentioned hill

2- The role of the hill as an inclination point in continuing the urban movement since its origin (Fig. 14.)

3- Conservation of different historical layers and aspects of its civilization

4- Adjustment to the old texture and active bazaar of the city (Fig.15.)

5- The distinguished topographical situation of the hill in the city

6- The tourist attractions

7- The valuable ancient treasures existing below its historical layers

B-Consequences and reflections of the negative aspects of the hill in the city

1 - Ruined and deserted and having no life as a historical natural hill in the city

2- Unsuitable city face
3- Distribution of pollution, caused by dispersion of unconsolidated soil of the ancient remains

4- The haunt of addicted men and criminals and misuse of the ruined ancient sites

5- Lack of social security

6- Education to counter the old and unsuitable form of this historical place.

However, it is noteworthy that the negative points of this historical hill are the result of wrong urban policies, which have turned this valuable national treasure into a serious problem and an insecure part of the city.

Therefore, considering all the factors above, including the obvious hereditary value of this land, a new approach in urban renovation, design and rehabilitation should be implemented. The authors conclude that:

This ancient city in its present situation suffers from so much damage that by reconstructing some parts of it, especially those for which sufficient documents exist, such as the fortification wall, we could at least rehabilitate a certain part of the city face.

In this renovation, we should always follow two great objectives:

1- Preserving the trenches and documents found in historical sites.

2-Activating of the historical site in the city.

Two types of functions seem to be effective in sharing the hill in today's city life:

- Educational and investigatory activities in the field of archeology.

- Tourism activities for the purpose of notifying people of the site in order to preserve the national historical cultural values of the country.

With respect to the different historical layers in the hill and lack of certainty in drawing the ambiguous parts, we should consider certain basic foundations for taking practical measures in reconstructing the place:

A- Protecting all historical layers

B-Composition of the existing layer pattern and new architectural ideas

C- Restorative renovation by using current technology, which responds to the necessity of resistance against earthquakes

D- Combining the historical perception and original pattern of the wall with education regarding it, using new methods

E- Presenting a way to educate people using old materials

F - Observing the recyclability principle in building the new layer

G- Using a light structural system in order not to damage the lower layers

$\mathrm{H}$ - Ambiguity concerning patterns of restoration and its application

Thinking and imagination in reconstruction of the real nature of the structure

I- Increasing people's responsibility regarding 
historical sites, while minimizing physical manipulation

J- Accepting different but complementary identities in the nature of critics

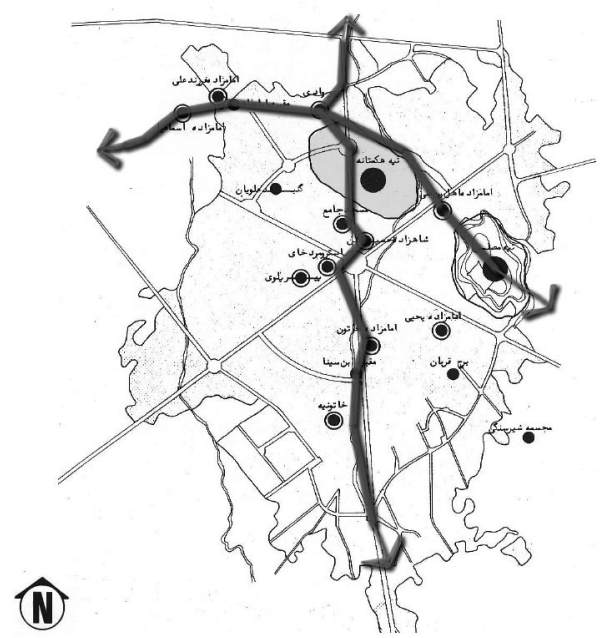

Fig.14. The Situation of Ekbatana Hill and other Historical and Religious Places in the City. Scale: 1/20000

Dividing the historical hill into two parts and allowing vehicles inside it has imposed heavy damage on the urban vision and its historical continuity.

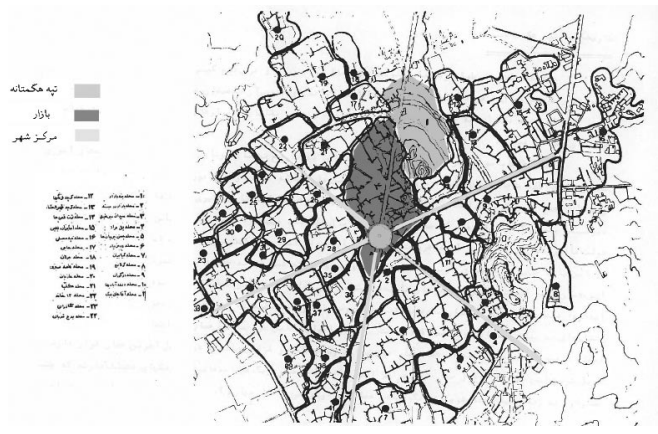

Fig.15. Location of the Hill, Bazaar and Old Part Adjacent to Each Other, and Closeness to the Central Point of the City.

Scale: $1 / 20000$

Close relation of the historical hill and bazaar as active elements in creating an opportunity in which these two elements define the place, can play an appropriate role in the design of a cultural historical plan for Hamedan city.

\section{Endnotes}

It seems that the Medians used colors in their architecture in imitation of Babylon. The Babylonians believed in colors as symbols of the seven asteroids, but the Medians simply applied an artistic imitation of these symbolic colors:

1- White

2- Black

3- Red

4- Blue

5- Orange

6- Gray

7- Yellow

2 Early $7^{\text {th }}$ century geographer.
Tel-Al-Emarne is a city between Cairo and Alghasr with just some part of it located on the east shore of the Nile River. The city was formed in society with reformation aims and was deserted after 2 years.

4 This confirms the historical tradition of the existence of the White Fortress with a round wall with four gates.

Name of a Place.

6 A cubit is a measure of length equal to $+0.45-0.56 \mathrm{~cm}$.

\section{References}

1) Diacnof, M. (2001) Historical Median. Translated by Keshavarz, Karim, Cultural Heritage Organization, p.176.

2) Evans, A. G. (1964) Herodots history. Translated by Mazandarani, Vahid, Tehran, p.79.

3) Hamedani E. F. (1970) MOKHTASAROLBALADAN. Translated by $\mathrm{H}$, Maoud, Tehran, p.110, p.65 and p.113.

4) Jacksen, E. V. (1978) Jacksen's travels, Iran in the past and present, translated by Amiri Manouchehr and Badrehyee Fereydoun, Tehran: Kharazmin, p.17, p.129, p.175 and p.178.

5) King, L. V. (1987) Historical Babylonian. Translated by Behzadi Roghayeh, Tehran: Cultural Scientific Organization.

6) Mehryar, M. (1982) Examination of the architectural factors of Ekbatana's Hill, Asar Magazine, Cultural Heritage Organization, p.80.

7) Minoreski, A. (1963) travels in Iran. Translated by Tabatayee, Abolfazl, Tehran, pp.66-68.

8) Mouris, J. (1989) Historical form of city until industrial revolution. Translated by Reza zadeh, Razieh, Tehran: Jahad daneshgahi Elmo sana'at, pp.24-25.

9) Saeednia, A., (2001) Herodots Hamedan Imagination, The second congress articles collection of historical architectural and city planning, Cultural Heritage Organization, p.319.

10) Saghafi, A. H., (2000) Plan of affair for Ekbatana Hill, Cultural Heritage Organization. (Not published), pp.64-95.

11) Sarraf, M. R. (2001) The method of architectural and city planning of ancient Ekbatana, The second architectural and city planning congress, Arq-e-Bam, Volume 1, Tehran: Cultural Heritage Organization, p.88, p.96, p.97 and p.100.

12) Sarfaraz, A. A. (2001) Archeological and historical art age, Tehran: Efaf.

13) Van 1., Maurits n. (1960) Urartian art, Nederland historicarchaelogistic instraunt, Istitaunt, Istanbul, pp.38-41.

14) Zarehyee, M. I. (2000) Acquaintance with world architecture. Fanavaran, Hamedan, p.75. 